\title{
Subclinical Mastitis and Antimicrobial Susceptibility of Staphylococcus caprae and Staphylococcus epidermidis Isolated from Two Italian Goat Herds
}

\author{
P. Moroni ${ }^{1}$ G. Pisoni, ${ }^{1}$ M. Antonini, ${ }^{2}$ G. Ruffo,${ }^{1}$ S. Carli, ${ }^{3}$ G. Varisco,${ }^{4}$ and P. Boettcher ${ }^{2}$ \\ ${ }^{1}$ Department of Animal Pathology, Hygiene, and Veterinary Public Health, University of Milan, Milan 20133, Italy \\ ${ }^{2}$ Institute of Agricultural Biology and Biotechnology (IBBA), National Research Council Milan 20133, Italy \\ ${ }^{3}$ Department of Veterinary Sciences and Technologies for Food Safety, University of Milan, Milan 20133, Italy \\ ${ }^{4}$ Department of Food Safety, Istituto Zooprofilattico of Lombardia and Emilia Romagna Brescia 25124, Italy
}

\section{ABSTRACT}

A total of 156 goats from 2 commercial dairy goat farms were monitored for intramammary infections during an entire lactation. Most of the infections $(80.7 \%)$ observed were due to coagulase-negative staphylococci (CNS) species. In herd 1, nearly all of the infections (96\%) were due to CNS species, with Staphylococcus caprae (SCAP) being the most common specific pathogen observed, accounting for about $43 \%$ of the infections. In herd 2, the proportion of the infections due to CNS was $67 \%$ and Staphylococcus epidermidis (SEPI) was the most common pathogen (48\% of infections) and SCAP was not present. Linear somatic cell scores (SCS) were greater in milk from infected udder halves, with an average difference of 0.78 SCS. The SCS for infected udder halves was greater than noninfected for all CNS species, although differences among species were observed. The ranking across CNS species was $\mathrm{SCAP}>$ other CNS > SEPI > no infection. However, infections by SEPI tended to be more persistent. Increased SCS was associated with a statistically significant decrease in milk yield, but no effect was observed for intramammary infections (IMI). Ninety-seven isolates of CNS (53 SCAP and 44 SEPI) were investigated for in vitro susceptibility to several antimicrobial agents. Benzylpenicillin was the most effective antimicrobial agent against SCAP and SEPI. A concentration of $0.05 \mu \mathrm{g} / \mathrm{mL}$ was sufficient to inhibit growth of $90 \%$ of SCAP colonies, and $0.10 \mu \mathrm{g} / \mathrm{mL}$ yielded a similar effectiveness for SEPI. Amoxicillin and the combination of amoxicillin and clavulanic acid were only slightly less effective. Tetracycline $(62.5 \mu \mathrm{g} / \mathrm{mL})$ and tilmicosin $(500 \mu \mathrm{g} / \mathrm{mL})$ were the least effective treatments for SEPI and SCAP, respectively.

Received October 18, 2004.

Accepted January 24, 2005.

Corresponding author: Paul J. Boettcher; e-mail: boettch@ibba. cnr.it.
(Key words: goat, coagulase-negative staphylococci, somatic cell count, antimicrobial susceptibility)

Abbreviation key: SCAP = Staphylococcus caprae, SEPI = Staphylococcus epidermidis .

\section{INTRODUCTION}

In Europe, the problem of mastitis is a highly relevant issue not only for the economic losses to producers, but also for the hygienic production of milk and the safety of dairy products for human consumption, particularly with respect to bacteriological quality (E.U. directives $46 / 92$ and 71/94). In Italy, hygiene and bacteriological quality of goat milk are defined by a specific law (DPR 54/97) that deals with different aspects of milk and cheese production. Regarding the bacterial count in milk, this law specifies maximum allowable levels, but, in contrast to production of bovine milk, no threshold value is defined for SCC. Nevertheless, udder health is critical for hygienic production of milk and cheese, and therefore, the control of IMI is of great importance for dairy goats as well as cattle. Subclinical and chronic IMI are of primary interest for goats, because they are the most persistent and widespread forms of IMI affecting milk-producing breeds of goats (Bergonier et al., 2003).

Coagulase-negative staphylococci are the most prevalent organisms detectable on udder skin, inside the streak canal, and in mammary glands of dairy goats and sheep. Various CNS species are commonly detected in goat milk and these microorganisms can frequently cause subclinical infections persisting for several months, even through the dry period (Poutrel, 1984; East et al., 1987). In caprine IMI, the CNS are the most prevalent microorganisms (ranging from 25 to $93 \%$ of IMI, depending on the study), and are isolated mainly from chronic and subclinical infections (Bergonier et al. 2003). Among the CNS, Staphylococcus caprae (SCAP) is the most prevalent species, followed by $S$. epidermidis (SEPI), S. xylosus, S. chromogenes, and S. simulans. The SEPI species is the CNS usually associated with 
the highest values of SCC (Deinhofer and Pernthaner, 1995; Contreras et al., 1999). The relevance of CNS as potential udder pathogens is widely controversial, but it has been established that these microorganisms often cause persistent subclinical mastitis (El Idrissi et al., 1994; Contreras et al., 1997) with related damage to mammary tissues, decreased yield, and elevated SCC (Poutrel 1984; Gutierrez et al., 1990; Deinhofer and Pernthaner, 1993). In the goat mammary gland, the pathogenic importance of CNS is still uncertain, and the pathogenic differences among the various CNS species are unclear. In dairy cows and ewes, subclinical IMI are recognized as important limiting factors in milk yield (Gonzalo et al., 1994; Fuertes et al., 1998) but this phenomenon has not yet been well documented in dairy goats. Little information is available about the decrease in milk yield, and the changes in protein and fat percentages and SCC caused by different CNS strains. Subclinical CNS infections increase SCC (Poutrel et al., 1997), cause damage to udder tissues (Burriel, 1997), and decrease milk yield (Gonzalo et al., 2002) in dairy ewes. Moreover, in a high percentage of cases, these IMI persist from one lactation to the next (Lerondelle and Poutrel, 1984; Poutrel, 1984; Watson and Buswell, 1984). These factors make antibiotic therapy necessary to control mammary infections and emphasize the need for mastitis control programs to improve milk quality and increase profits for dairy farmers. Antibiotic treatment during the dry period is one of the recommended approaches to reduce IMI. Indiscriminate use of antimicrobial agents for mastitis therapy (or any other reason), however, may cause an increase in the resistance of many microorganisms to these drugs. Little is known about the antimicrobial susceptibility of caprine CNS strains (Rodrigues da Silva et al., 2004); increased knowledge about the differences in bacterial susceptibility to antibiotics could improve the cure rates of IMI and reduce the risks of bacterial resistance.

The objectives of this study were to: 1) determine the influence of SCAP, SEPI, and other CNS bacteria on SCC and various milk production traits (such as milk yield and protein and fat percentages) in goats and examine the relationships between SCC and production in herds with the presence of these bacteria, and 2) evaluate in vitro the activity of antimicrobial agents against some strains of SCAP and SEPI isolated from infected udders.

\section{MATERIALS AND METHODS}

\section{Animals and Herds}

The study was performed on 2 commercial dairy farms in Italy, using 156 Alpine goats. Both farms were free of brucellosis, tuberculosis, mycoplasmosis, and caprine arthritis-encephalitis. The farms practiced seasonal milking and the goats (65 from farm 1 , and 91 from farm 2) were monitored during an entire lactation (from February to September 2002). The does kidded between January and February 2002. The herds remained housed throughout the study. The ration consisted of permanent pasture-alfalfa mixed hay available for ad libitum consumption, supplemented with $18 \%$ $\mathrm{CP}$ commercial dairy pelleted feed in the milking parlor according to lactation stage and an integration of microand macrominerals and vitamins. Water was available at all times. After weaning, all goats were machinemilked twice daily without teat preparation. Milking machines were set to a vacuum level of $45 \mathrm{kPa}$ with 85 pulsations/min, and a 1-to-1 aspiration to massage rate. In herd 1, the teat ends of every udder half were postdipped with chlorhexidine, whereas in herd 2 teat dipping was not practiced. Farm workers did not use gloves to prevent bacterial transmission during the milking process. No dry therapy was practiced in either herd. No cases of clinical IMI were observed in either herd during the sampling period, but clinical IMI occurs much less frequently in goats than does subclinical IMI (Bergonier et al., 2003). Because no clinical IMI were observed, no animals were treated with antibiotics during the course of the study. The primary reasons for culling of goats from the herd were low production and reproductive failure. Culling for presence of IMI was generally not practiced.

\section{Milk Sampling}

Foremilk samples were obtained monthly (from February to September 2002) by the technicians of the Provincial Breeding Association (APA) as part of the usual quality control. Numbered collars were used to identify the goats in each herd and no goats showed evidence of clinical mastitis at the time of sampling. Teat ends were cleaned with chlorhexidine before sampling. The first streams of foremilk were discharged, and then 10 $\mathrm{mL}$ of milk was collected aseptically from each half udder into sterile vials. Samples were kept at $4^{\circ} \mathrm{C}$ until bacteriological assays and SCC tests were performed. Samples of pooled milk (across udder halves) were collected later in the milking process and tested for fat and protein concentrations (\%); the daily milk yield (kg) was recorded at the same time.

\section{Bacteriological Procedures}

Ten microliters of each milk sample was spread on blood agar plates (5\% defibrinated sheep blood). The plates were incubated aerobically at $37^{\circ} \mathrm{C}$ and exam- 
ined after $24 \mathrm{~h}$. The colonies were provisionally identified based on Gram stain, morphology, and hemolysis pattern, and the numbers of each colony type were recorded. The representative colonies were then subcultured on blood agar plates and incubated aerobically at $37^{\circ} \mathrm{C}$ for $24 \mathrm{~h}$ to obtain pure cultures. Catalase and coagulase production was tested for gram-positive cocci. Specific identification of staphylococci was made using commercial micromethods (API Staph; BioMérieux, Italy). The infection status of milk samples was defined according to the procedures recommended by National Mastitis Council (NMC, 1987) and IMI was diagnosed when $\geq 500 \mathrm{cfu} / \mathrm{mL}$ and 1 to 3 colony types were isolated. Milk samples from which many colony types or $<500$ $\mathrm{cfu} / \mathrm{mL}$ of any microorganism were isolated were regarded as contaminated or uninfected, respectively. Prevalence was defined as the number of halves (or goats) from which a pathogen was isolated divided by the total number of halves (or goats) sampled at each time period.

\section{Determination of SCC}

For each sample, the SCC was determined by an automated fluorescent microscopic somatic cell counter (Bentley Somacount 150, Bentley Instruments, Dublin, Ireland). Ethidium bromide dye was used for specific binding to the DNA in the cell nuclei. For statistical analyses, the SCC were normalized to linear somatic cell scores (i.e., SCS) using the standard $\log 2$ transformation of Ali and Shook (1980), which is SCS = $\log _{2}(\mathrm{SCS} / 1000)+3$.

\section{Determination of Protein and Fat Percentages}

Milk yield of individual goats was recorded monthly at morning milking using recording jars in the milking parlor. Percentages of milk fat and protein were determined on composite milk samples and assayed by an automated Fourier Transform infrared absorption spectrophotometric analyzer (Milkoscan, Foss Electric, Hillerød, Denmark). Milk yield (kg/milking) was multiplied by these percentages to obtain yields for fat and protein.

\section{Statistical Analyses}

SCS and infection. Linear mixed models were used to examine the relationships among SCC (defined as SCS), bacterial infection, and milk production traits. For SCS and bacterial infection, data were available for each udder half, so the udder halves of the same goat were considered different experimental units. Both SCS and bacterial infection data were required to be present. This requirement resulted in 2401 observations from 310 udder halves (2 goats had useable data only from a single udder half). The following linear model was used to examine the relationship between SCS and infection:

$$
\begin{gathered}
y_{i j k l m n}=h_{i}+d_{j}+h d_{i j}+s_{k}+i_{l} \\
+g_{m}+q_{m n}+e_{i j k l m n},
\end{gathered}
$$

where $y_{\mathrm{ijk} k m n}$ is the observation of SCS taken from udder half $q$ of goat $m$ on the jth test day for farm $i ; h_{i}, d_{j}$, and $\mathrm{hd}_{\mathrm{ij}}$ are the respective main and interaction (fixed) effects for farm $i$ and test day $j ; s_{k}$ is the fixed effect of udder side (left or right); $i_{l}$ is the fixed effect of udder infection; $g_{m}$ is the random effect of goat $m ; q_{m n}$ is the random effect of the nth udder half (nested within the $\mathrm{m}$ th goat); and $\mathrm{e}_{\mathrm{ijk} \mathrm{mn}}$ is the random residual. The $\mathrm{g}_{\mathrm{m}}$ and $q_{m n}$ effects accounted for the fact that repeated observations were available for each goat and udder half within goat. Two separate analyses were performed with different definitions for the effect of infection. For the first analysis, the infection effect had 2 classes, healthy and infected. For the second analysis, the infected class was subdivided into 5 groups: 1) SEPI, 2) SCAP, 3) other CNS, 4) Staph. aureus, and 5) other bacteria. Differences between the effects of the various CNS bacteria were of particular interest in this study and the results presented will emphasize those pathogens. All statistical analyses were performed using the procedure MIXED in SAS (SAS Institute, Inc., Cary, NC).

Another interesting characteristic regarding bacteria was the frequency of simultaneous IMI across udder halves. Coagulase-negative staphylococci are naturally found on the skin of animals and could be expected to commonly infect both udder halves simultaneously. This characteristic was evaluated by determining the proportion of goats infected bilaterally by a given microorganism compared with the proportion infected in only a single udder half. Differences were tested with simple $\chi^{2}$ tests.

Production and SCS. An analysis of residuals was used to evaluate the relationship between production traits (kilograms of milk, fat, and protein, as well as fat and protein percentages) and SCS. For SCS, residuals were taken from an analysis similar to that defined by equation [1], but without the effect for bacterial infection. For production traits, the model included fixed effects of farm, test day, the interaction of these effects, and the random effect of goat. Effects of udder half were not necessary in the model for production traits, because milk yield was recorded for the whole animal. Because production data were recorded on the whole animal basis, whereas SCS was recorded on each udder 
half, residuals for SCS from each udder half from the same goat on the same day were averaged. Then, to test for relationships between production and SCS, the residuals for production traits on a given test day were regressed on the average residuals for SCS for the corresponding goat on the same test day. A simple t-test was used to determine significance.

Production and infection. Two analyses were applied to define the relationship between production traits and infection status. As mentioned previously, mastitis and SCS data were generally available on both udder halves, whereas production traits were recorded on a whole-animal basis. Thus, for a given test day, each production trait was regressed on the number of udder halves infected according to the following model equation:

$$
y_{i j k}=h d_{i}+g_{j}+\sum_{k=1}^{N_{b}} X_{i j k} b_{j}+e_{i j k},
$$

where $y_{i j k l m}$ is a test day observation for a given production trait, from goat $\mathrm{k}$ in herd-test day $\mathrm{i} ; \mathrm{hd}_{\mathrm{i}}$ is the fixed effect of herd-test day $i, g_{j}$ is the random effect of the $j$ th goat, $X_{\mathrm{ijk}}$ is the number of udder halves of goat $j$ infected by bacteria $\mathrm{k}$ on herd-test day $\mathrm{i}\left(\mathrm{X}_{\mathrm{ijk}}=0,1\right.$, or 2 ); $\mathrm{N}_{\mathrm{b}}$ is the number of different types of bacteria, $\mathrm{b}_{\mathrm{j}}$ is the regression coefficient of the production trait on number of udder halves infected, and $\mathrm{e}_{\mathrm{ijk}}$ is the random residual. In the first analysis, all bacteria types were grouped together and $\mathrm{N}_{\mathrm{b}}=1$; in the second, bacteria groups were defined as previously described, so $\mathrm{N}_{\mathrm{b}}=5$.

Duration and persistence of infections. In addition to the concurrent (i.e., on the same test day) relationships among infection, SCS, and milk production traits, aspects of the duration of infections by the various CNS bacteria across lactation (i.e., in the absence of treatment) were also of interest. A simple test was used to compare the duration of infections by the various species. An infection was defined as a string of consecutive (across months) occurrences of the same bacteria in the same udder half of the same goat. Duration was then defined as the number of consecutive positive test days for each infection and could range from 1 to $10 \mathrm{mo}$. This definition assumed that consecutive observations of the same bacterial species in the same udder half resulted from the maintenance of the same initial infection, rather an initial infection followed by recovery and a reinfection. This approach identified 406 different infections in 249 udder halves of 142 goats (i.e., some goats had infections in only one udder half).

The first analysis evaluated the duration of infections as a function of bacterial species. The following mixed linear model was used:

$$
\mathrm{y}_{\mathrm{ilkjm}}=\mathrm{h}_{\mathrm{i}}+\mathrm{b}_{\mathrm{j}}+\mathrm{g}_{\mathrm{k}}+\mathrm{q}_{\mathrm{kl}}+\mathrm{e}_{\mathrm{ijklm}},
$$

where $y_{i j k l m}$ was the duration of the mth infection by the jth bacteria in the lth udder half of the kth goat in the ith herd, $h_{i}$ was the random effect of the ith herd, $b_{j}$ was the fixed effect of the jth bacteria, $g_{k}$ was the random effect of the kth goat, $\mathrm{q}_{\mathrm{kl}}$ was the random effect of the lth udder half (nested within the kth goat), and $\mathrm{e}_{\mathrm{ijklm}}$ was the random residual. Least squares means were calculated for the different bacteria species.

A second set of analyses evaluated relationships between the duration of infections and SCS and the milk production traits. For these analyses, a new variable was introduced, the "persistency" of an infection. For a given observation with a positive bacterial test, the persistency of the infection was defined as the number of consecutive months that bacteria had been present, up to and including the current month. For example, the initial positive test in a given udder half had a persistency of 1 , and the last observation of an infection that was present throughout the lactation was assigned a persistency of 10 . Observations with bacteria present had a persistency equal to zero. In addition to defining the persistency of an infection, another term was defined, namely that for a "chronic" infection. Any infection that lasted for at least 3 mo was defined to be chronic. Thus, persistency of infection had 3 levels: 1) chronic, 2) short term, and 3) free from infection. The following linear model was used to test the relationship between SCS and persistency, and duration of the infection:

$$
\begin{gathered}
\mathrm{y}_{\mathrm{ijklmno}}=\mathrm{h}_{\mathrm{i}}+\mathrm{d}_{\mathrm{j}}+\mathrm{hd}_{\mathrm{ij}}+\mathrm{a}_{\mathrm{k}}+\mathrm{b}_{\mathrm{l}}+\mathrm{p}_{\mathrm{m}} \\
+\mathrm{ap}_{\mathrm{km}}+\mathrm{bp}_{\mathrm{lm}}+\mathrm{g}_{\mathrm{n}}+\mathrm{q}_{\mathrm{no}}+\mathrm{e}_{\mathrm{ijkl} \mathrm{k} n \mathrm{n}},
\end{gathered}
$$

where $\mathrm{y}_{\mathrm{ijk} \text { lmno }}$ is the observation of SCS taken from udder half $q$ of goat $p$ on the jth test-day for farm $i ; h_{i}, d_{j}$, are $h d_{i j}$, are the same as in equation [1]; $a_{k}$ is the fixed effect the infection persistency; $b_{1}$ is the effect of bacterial species $1, p_{m}$, is the effect of duration level $\mathrm{m}$, and $\mathrm{ap}_{\mathrm{km}}$ and $\mathrm{bp}_{\mathrm{lm}}$ are the 2-way interactions of these effects; and $g_{n}, q_{n o}, e_{i j k l m n o}$ are as in equation [1].

A similar analysis was performed for the milk production traits (i.e., yields of milk, fat, and protein, and concentrations of fat and protein). For these analyses, the dependent variables were the residuals for production traits (accounting for effects of herd, test day, and goat), calculated as described previously. As already explained, production traits were taken for the whole goat, whereas infection information was taken from each udder half. Therefore, for a given test day, 2 observations of infection were available, but only one observation for production. Therefore, for each record of production, several new duration variables were created. 
The first was simply the duration (in months) of the most persistent bacterial infection present in either udder half on the test day from which the milk record was taken. A second set of variables consisted of 1) the number of udder halves (i.e., 0,1 , or 2 ) with the presence of a chronic infection by each bacterial species and 2) the number of udder halves with a short-term infection by each bacteria. This approach yielded a total of 1220 records. Two linear models were analyzed. The first model regressed the production traits on the first variable (i.e., the number of consecutive months infected by the same bacteria in either udder half). The second model regressed the production traits on the second set of variables (i.e., the numbers of udder halves with the presence of chronic and short term infections for each bacterial species). In other words, the second analysis considered all infection types and bacterial species together in the same model.

\section{MIC Tests}

The SEPI (44 strains) and SCAP (53 strains), isolated from different goats throughout the lactation, were stored frozen until antimicrobial susceptibility tests could be performed. Antibiotics were selected based upon their routine use in dairy cattle for mastitis treatment. They included the following: benzylpenicillin, cloxacillin, amoxicillin, amoxicillin plus clavulanic acid, cephalonium, cephoperazone, erythromycin, tilmicosin, kanamycin, and tetracycline. All the antibiotics tested, except cephalonium, cephoperazone and tilmicosin, were included in a comprehensive list of antimicrobial agents for routine testing of bovine mastitis pathogens by the National Committee for Clinical Laboratory Standards (NCCLS, 1997). They were provided in powder form by the respective manufacturers. The antibiotics were dissolved in suitable solvents to make stock solutions and then diluted in sterile distilled water according to their methods (NCCLS, 1997). Minimum inhibitory concentration tests were performed according to the microdilution broth method as recommended (NCCLS, 1997), using 96-well microtiter plates. Serial 2 -fold dilutions of the antimicrobial agents were prepared starting from the stock solution of each drug. Dilution schemes differed according to the antibiotic and to the microorganism tested. Inocula were prepared by diluting an overnight Mueller-Hinton Broth culture in buffered saline solution to a density of 0.5 on the McFarland turbidity scale and finally diluting again 40fold before testing. The MIC was defined as the lowest concentration of antibiotic at which bacterial growth was completely inhibited. A reference strain of Staph. aureus (ATCC 29213) was inoculated as a control on each plate. The MIC data were summarized by calculat-
Table 1. Percentage distribution of bacterial infections in 2 herds.

\begin{tabular}{lccc}
\hline Bacteria isolates & $\begin{array}{l}\text { Herd 1 } \\
(\mathrm{n}=1162)\end{array}$ & $\begin{array}{l}\text { Herd 2 } \\
(\mathrm{n}=1239)\end{array}$ & $\begin{array}{l}\text { Overall } \\
(\mathrm{n}=2401)\end{array}$ \\
\cline { 2 - 4 } & \multicolumn{4}{c}{$\%$} \\
\cline { 2 - 4 } All & 48.0 & 51.6 & 49.8 \\
Staphylococcus caprae & 20.9 & 0.0 & 10.1 \\
Staphylococcus epidermidis & 0.0 & 24.8 & 12.8 \\
Other CNS & 25.4 & 9.8 & 17.3 \\
Staphylococcus aureus & 1.2 & 2.0 & 1.8 \\
Other & 0.5 & 15.0 & 7.8 \\
\hline
\end{tabular}

ing the 50th and 90th percentiles (i.e., $\mathrm{MIC}_{90}=\mathrm{MIC}$ required to inhibit growth for $90 \%$ of the isolates tested and $\mathrm{MIC}_{50}=\mathrm{MIC}$ required to inhibit $50 \%$ of the isolates tested), as well as the range of MIC values required to prevent growth of any (minimum) and all (maximum) strains. Isolates were categorized as susceptible or resistant based upon MIC breakpoint developed for bovine mastitis pathogens (NCCLS, 1997). The CNS were tested for $\beta$-lactamase production by the Nitrocefin test (Dry Slide Nitrocefin, Difco Laboratories, Detroit, MI).

\section{RESULTS AND DISCUSSION}

\section{Descriptive Statistics}

Table 1 shows the distribution of infections across herds. Infection rate was high relative to rates reported elsewhere (Contreras et al., 1999; Moroni et al., 2004), with nearly $50 \%$ of the samples showing presence of bacteria. Table 2 summarizes descriptive statistics for the production traits and SCS. Production traits are within the normal range for Alpine goats in Italy (ASSONAPA, 2004). As mentioned previously, these herds had relatively high rates of infection and, not surprisingly, SCS was greater than typically observed for milking goats.

\section{Infection Rates}

Prevalence of IMI (Table 1) may be explained by the management of the 2 herds. No selective or systematic

Table 2. Descriptive statistics for SCS and production traits across both herds $(\mathrm{n}=1220)$.

\begin{tabular}{lll}
\hline Trait $^{1}$ & Mean & SD \\
\hline Milk, kg & 1.90 & 0.97 \\
Fat, kg & 0.061 & 0.030 \\
Protein, kg & 0.060 & 0.027 \\
Fat concentration, \% & 3.31 & 0.83 \\
Protein concentration, \% & 3.28 & 0.52 \\
Linear SCS & 5.61 & 2.56 \\
\hline
\end{tabular}

${ }^{1}$ Production traits were composite values from both udder halves, whereas SCS were from each udder half. 
dry therapy was used, no consistent milking order was used, and no culling of goats with chronic IMI (either clinical or subclinical) occurred. These procedures represent the main factors affecting the diffusion of IMI (Kalogridou-Vassiliadou, 1991) and these herds did not generally follow these preventive strategies. Most $(80.7 \%)$ of the infections were due to CNS species. In herd 1, nearly all (96\%) of the infections were due to CNS species, with SCAP being the most common specific pathogen observed, accounting for about $43 \%$ of the infections. In herd 2, SEPI was the most common pathogen (48\%) and SCAP was not present. Other than CNS bacteria, Staph. aureus was the most common pathogen observed in both herds. However, only about $2 \%$ of all samples showed presence of these bacteria. The other species were considered environmental pathogens (Streptococcus spp., Enterococcus spp., coliforms). These results regarding the distribution of pathogens correspond well with other studies on IMI in dairy goats worldwide (Boscos et al., 1996; Ndegwa et al., 2001; Leitner et al., 2004), in which CNS are the predominant organisms isolated from bacteriological positive milk samples. The large proportion of CNS infections is consistent with the absence of clinical IMI; in fact, some authors have proposed CNS as etiological agents of subclinical IMI in goats (Poutrel, 1984; Leitner et al., 2004), cows (Smith and Hagstad, 1986), and sheep (Fthenakis et al., 1994). In addition, Staph. aureus, whose role in clinical mastitis in goats has been clearly defined (Maisi and Riipinen, 1991), was rare in this study, and subclinical infections by Staph. aureus are also common in goats (Moroni et al., 2004). Different factors could explain the presence of SCAP in herd 1 and of SEPI in herd 2 (Table 1). Several studies have demonstrated the capacity of SCAP to persist throughout lactation (e.g., Poutrel et al., 1996; Contreras et al., 1997) and during the dry period (Poutrel, 1984). Persistence of SCAP during the dry period could be a risk factor for the next lactation because of possible expression of virulence factors during the periparturient period when defense mechanisms of the udder are diminished (Sordillo et al., 1997). No dry therapy could be one reason for the high prevalence of this pathogen in herd 1. Our findings on SEPI in herd 2 agree with another study (Contreras et al., 1999) in which a commercial dairy goat herd had a history of high SCC in bulk tank milk. Staphylococcus epidermidis accounted for $30 \%$ of the isolates, and major pathogens, such as Staph. aureus, other Streptococci spp., or gram-negative bacilli, were isolated infrequently. Hogan et al. (1987) found that SEPI was the predominant Staphylococcus $(37.1 \%)$ for lactating dairy cows when teat dipping was not practiced. This trend was observed in dairy goats by the high percentage of SEPI isolated in this
Table 3. Least square means of linear SCS from infected and uninfected udder halves across herds for all infections and infections by specific pathogens.

\begin{tabular}{lll}
\hline & \multicolumn{2}{c}{ SCS } \\
\cline { 2 - 3 } Bacterial isolates & Mean & SE \\
\hline Model 1 & $5.44^{\mathrm{a}}$ & 0.07 \\
Uninfected & $6.22^{\mathrm{b}}$ & 0.08 \\
All & $5.39^{\mathrm{a}}$ & 0.08 \\
Model 2 & $6.46^{\mathrm{b}}$ & 0.13 \\
Uninfected & $5.99^{\mathrm{c}}$ & 0.14 \\
Staphylococcus caprae & $6.05^{\mathrm{c}}$ & 0.10 \\
Staphylococcus epidermidis & \\
Other CNS & & \\
\hline a,b,c Values from the same model having different superscripts differ \\
$(P<0.01)$.
\end{tabular}

study and found by Poutrel (1984) in goat herds that did not practice teat dipping (47.7\%). This effect of teat dipping might explain the low prevalence of SEPI in herd 1 in this study, where postmilking teat dipping was practiced. Another factor leading selection of a particular species among the CNS could be competition during udder colonization, as observed in dairy cattle when IMI are caused by CNS (Matthews et al., 1991; Lam et al., 1997).

No significant differences were observed among the 3 CNS groups in unilateral or bilateral distribution of infections because the proportion of times in which both udder halves were infected ranged from 24 to $27 \%$ for SEPI, SCAP, and other CNS. In contrast, this characteristic was evaluated for bacteria that could be classified as environmental (among the "other" bacterial group) and only $7 \%$ of goats infected by these species were infected bilaterally.

\section{SCS and Infection}

Effects of herd, test day, and the interaction of herd and test day on SCS were significant $(P<0.001)$. The SCS tended to be lowest in early lactation and increasing as lactation progressed. This trend was likely due in part to effects of dilution and was previously observed in goats (Luengo et al., 2004; Moroni et al., 2004) and dairy cattle (Reents et al., 1995). No association was observed between SCS and the side of the udder (right or left) from which the milk sample was taken. Table 3 shows differences in least squares means for SCS between healthy and infected udder halves. Results are presented for all isolates together and then for each of the CNS groups. The SCS was greater $(P<0.05)$ in milk from infected udder halves, with an average difference of nearly 1 SCS (0.78). The SCS for infected udder halves was greater $(P<0.05)$ than for noninfected halves for all CNS species, although differences among 
Table 4. Coefficients of residual ${ }^{1}$ regression for production traits on mean SCS between udder halves from the same goat.

\begin{tabular}{lll}
\hline Trait & $\begin{array}{l}\text { Regression } \\
\text { coefficient }\end{array}$ & $\mathrm{SE}$ \\
\hline Milk, kg & $-0.035^{* *}$ & 0.008 \\
Fat, kg & -0.0006 & 0.0003 \\
Protein, kg & $-0.0008^{* *}$ & 0.0003 \\
Fat concentration, \% & 0.020 & 0.011 \\
Protein concentration, \% & $0.023^{* *}$ & 0.006 \\
\hline
\end{tabular}

${ }^{1}$ Factors in model included fixed herd-test-day and random goat effects.

**Different $(P<0.001)$ from zero.

species were observed. The ranking across CNS species was SCAP $>$ other CNS $>$ SEPI $>$ no infection. The effect of SCAP on SCS was greater $(P<0.05)$ than for SEPI and other CNS. In turn, the effect of SEPI on SCS did not differ from the other CNS. Sanchez et al. (2002) reported results on infection by SCAP for which no significant effects on SCS were observed, but their results were based on only 10 goats. Contreras et al. (1999) reported greater SCS for SEPI than for other CNS, but, similar to our study, the difference was not significant. No specific test for effects of SCAP on SCS was made in that study.

\section{Production Traits, SCS, and Infection}

Table 4 shows residual regression coefficients for production traits on SCS. Increased SCS was associated with decreased $(P<0.001)$ milk yield. Most studies about phenotypic relationships between production and SCS in dairy cattle have shown that high SCS is associated with decreased milk yield (Boettcher et al., 1992). Despite the significant difference, the practical effect in terms of kilograms per day was rather small. Specifically, the regression coefficient was -0.03 , indicating that production was expected to decrease by only about $1.5 \%$ for every unit difference in SCS. The SCS is expressed on a $\log _{2}$ basis, so a difference of 1 SCS reflects a doubling of SCC. Increased SCS was also associated with decreased yield of protein, despite a positive association with protein percentage (possibly due to effects of dilution with decreased milk yield). Relationships of SCS with fat yield and concentration were not significant. Very few statistically significant relationships between production traits and number of udder halves infected by the various CNS bacteria were observed, and those effects that were significant were small from a practical point of view (data not shown). When production traits were regressed on number of udder halves infected by any pathogen, a significant $(P<0.05)$ relationship was observed only for protein yield. Infection was associated with a slight increase in protein yield
Table 5. Least square means of duration (number of consecutive positive tests) of (untreated) infections by bacterial species across herds.

\begin{tabular}{|c|c|c|c|}
\hline \multirow[b]{2}{*}{ Bacterial isolates } & \multirow[b]{2}{*}{$\mathrm{n}$} & \multicolumn{2}{|c|}{ Duration, mo } \\
\hline & & Mean & SE \\
\hline Staphylococcus caprae & 78 & $1.3^{\mathrm{a}}$ & 0.27 \\
\hline Staphylococcus epidermidis & 86 & $3.4^{\mathrm{b}}$ & 0.26 \\
\hline Other CNS & 160 & $1.9^{\mathrm{c}}$ & 0.18 \\
\hline
\end{tabular}

of $1.3 \mathrm{~g} /$ milking per udder half infected. Most of this effect seemed to be due to SEPI, because a similar result was observed when yield was specifically regressed on numbers of udder halves infected by SEPI. Fat and protein yield were greater from goats infected by SEPI, by 3.1 and $3.3 \mathrm{~g} /$ milking of fat and protein, respectively, for each udder half infected. No other significant relationships were observed between production traits and IMI. These results seem to contradict the general consensus that mastitis leads to decreased production. Two plausible explanations exist. First, IMI is likely to increase the presence of immunoglobulins (i.e., proteins) in milk. However, this possibility is unlikely to be the only factor. Increased immunoglobulins in milk should lead to greater concentrations of protein, and no significant relationship between IMI and protein percentage was observed. A second, perhaps more abstract, explanation for greater production among infected goats may be that goats with increased genetic potential for production are more susceptible to both clinical and subclinical IMI. In dairy cattle, results from selection experiments (Heringstad et al., 2003) and positive estimates of genetic correlations between yield and clinical IMI (Pösö and Mäntysaari, 1996) demonstrated that higher-producing cows are more likely to contract mastitis, possibly due to compromised immune function. A similar relationship also may exist for goats, although this relationship has not been studied directly.

\section{Duration of Infections}

Table 5 reports the results regarding the duration of infections according to the different CNS bacterial species. Again, no treatments were applied throughout the study. Infections by SEPI (3.4 consecutive samples) tended to persist longer $(P<0.05)$ than did infections by SCAP and other CNS pathogens. Of the SEPI infections, $40 \%$ lasted longer than $2 \mathrm{mo}$, and $20 \%$ persisted for 6 or more months. On the other hand, the infections caused by SCAP generally had a much shorter duration. No SCAP infection remained present for more than 5 consecutive months. 
Table 6. Effect of persistency of infections on SCS.

\begin{tabular}{lrll}
\hline \multirow{2}{*}{$\begin{array}{l}\text { Persistency, } \\
\text { mo }\end{array}$} & & \multicolumn{2}{c}{ SCS } \\
\cline { 3 - 4 } \cline { 3 - 4 } Noninfected $^{1}$ & No. & Effect & SE \\
1 & 1201 & $0.00^{\mathrm{c}}$ & 0.26 \\
2 & 623 & $0.78^{\mathrm{a}}$ & 0.26 \\
3 & 220 & $0.87^{\mathrm{a}}$ & 0.27 \\
4 & 132 & $0.75^{\mathrm{a}}$ & 0.28 \\
5 & 78 & $0.68^{\mathrm{a}}$ & 0.30 \\
6 & 55 & $0.44^{\mathrm{ab}}$ & 0.31 \\
$>7^{2}$ & 39 & $0.18^{\mathrm{bc}}$ & 0.33 \\
\hline
\end{tabular}

a,b,c Estimates having different superscript letters differed $(P<0.05)$.

${ }^{1}$ Reference group.

${ }^{2}$ Persistency classes for 8,9 , and 10 mo had 18, 2, and 1 observations, respectively.

All effects regarding duration of infection in equation [4] were significant $(P \leq 0.005)$. Table 6 shows how SCS varied as a function of the persistency of the infection. The greatest elevation in SCS was observed in the early to mid stages of an infection. Relative to freedom from infection, SCS was elevated by from about 0.70 to 0.90 SCS units during the first 4 mo of infection. After this point, SCS tended to decrease and was only numerically greater than in healthy udders for infections that had already been present for 7 or more months. This small difference in SCS late in lactation may suggest that the immune system of the goat actively tries to eliminate the infection at first, but an equilibrium state is eventually reached at which an immune response is no longer generated. Table 7 shows the effects of chronic and short-term infections on SCS. Table 8 shows the differences between these 2 persistencies of infections according to CNS species. Considering all bacterial species together, chronically persistent infections were associated with greater elevation in SCS than were shortterm infections. Both types were associated with increases relative to healthy udder halves. This general trend was observed for all species of CNS; however, the difference was especially large for SEPI and the "other

Table 7. Estimated effects (difference in least square means) of persistent $^{1}$ and nonpersistent infections on SCS.

\begin{tabular}{lccc}
\hline & & \multicolumn{2}{c}{ SCS } \\
\cline { 3 - 4 } Infection type & No. & Mean & SE \\
\hline Chronic & 618 & $0.36^{\mathrm{a}}$ & 0.11 \\
Short-term ${ }^{2}$ & 579 & $0.00^{\mathrm{b}}$ & $\ldots .09$ \\
Noninfected & 1204 & $-0.66^{\mathrm{c}}$ & 0.09 \\
\hline${ }^{1}$ Chronic infections were those for which the same bacterial species \\
was observed in the same udder half in at least 3 consecutive monthly \\
samples. \\
$\quad{ }^{2}$ Reference group. \\
$\quad * P<0.05 ; * * P<0.01$.
\end{tabular}

Table 8. Differences between least square means of SCS for chronic and short-term infections according to bacterial species.

\begin{tabular}{|c|c|c|c|}
\hline \multirow[b]{2}{*}{ Species } & \multirow{2}{*}{$\begin{array}{l}\text { No. } \\
\text { (chronic/ } \\
\text { short-term) }\end{array}$} & \multicolumn{2}{|c|}{ SCS } \\
\hline & & Difference $^{2}$ & $\mathrm{SE}$ \\
\hline Staphylococcus caprae & 196/111 & 0.38 & 0.26 \\
\hline Staphylococcus epidermidis & $81 / 162$ & 0.52 & $0.23 *$ \\
\hline Other CNS & $182 / 234$ & 0.58 & $0.19 * *$ \\
\hline
\end{tabular}

${ }^{1}$ Chronic infections were those for which the same bacterial species was observed in the same udder half in at least 3 consecutive monthly samples.

${ }^{2}$ Chronic minus short-term.

$* P<0.05 ; * * P<0.01$.

CNS" group, whereas the difference was not significant for SCAP. Differences in SCS between chronic and short-term infections (and healthy udders) were especially large in the first 2 mo of the infections (Table 9). Infections that eventually became chronically persistent were associated with a much more elevated SCS in the first 2 mo of the infection than were infections that were no longer detectable after 2 mo or less. In the month when the infections were initially detected (i.e., persistency $=1$ ), the infections that eventually became chronically persistent were associated with an SCS 1.38 greater than in noninfected udder halves. This difference was only 0.67 for the short-term infections that were quickly eliminated. This finding may indicate that SCS is useful information to consider whether to treat an animal with antibiotics, beyond the simple presence and species of bacteria.

No significant relationships were observed between duration of infections and any of the milk production traits. This result was not too surprising, considering that few concurrent effects (i.e., from equation [2]) of infection were observed, and indicates that the chronically persistent infections were not causing significant damage to secretory tissues.

Table 9. Differences between least square means for SCS corresponding to the interaction between the persistency of the infection and the type of infection.

\begin{tabular}{lllll}
\hline \multirow{2}{*}{$\begin{array}{l}\text { Persistency, } \\
\text { mo }\end{array}$} & & & \multicolumn{2}{c}{ SCS } \\
\cline { 3 - 5 } 1 & & Type $^{1}$ & Difference & SE \\
\hline & Chronic & Noninfected & 1.38 & 0.16 \\
& Short-term & Noninfected & 0.67 & 0.09 \\
& Chronic & Short-term & 0.71 & 0.16 \\
& Chronic & Noninfected & 1.14 & 0.16 \\
& Short-term & Noninfected & 0.61 & 0.18 \\
& Chronic & Short-term & 0.53 & 0.22 \\
\hline
\end{tabular}

\footnotetext{
${ }^{1}$ Chronic infections were those for which the same bacterial species was observed in the same udder half in at least 3 consecutive monthly samples and short-term infections lasted less than 3 mo.
} 
Table 10. Antimicrobial susceptibility of strains of Staphylococcus caprae (SCAP) and Staphylococcus epidermidis (SEPI) isolated from different animals throughout the lactation.

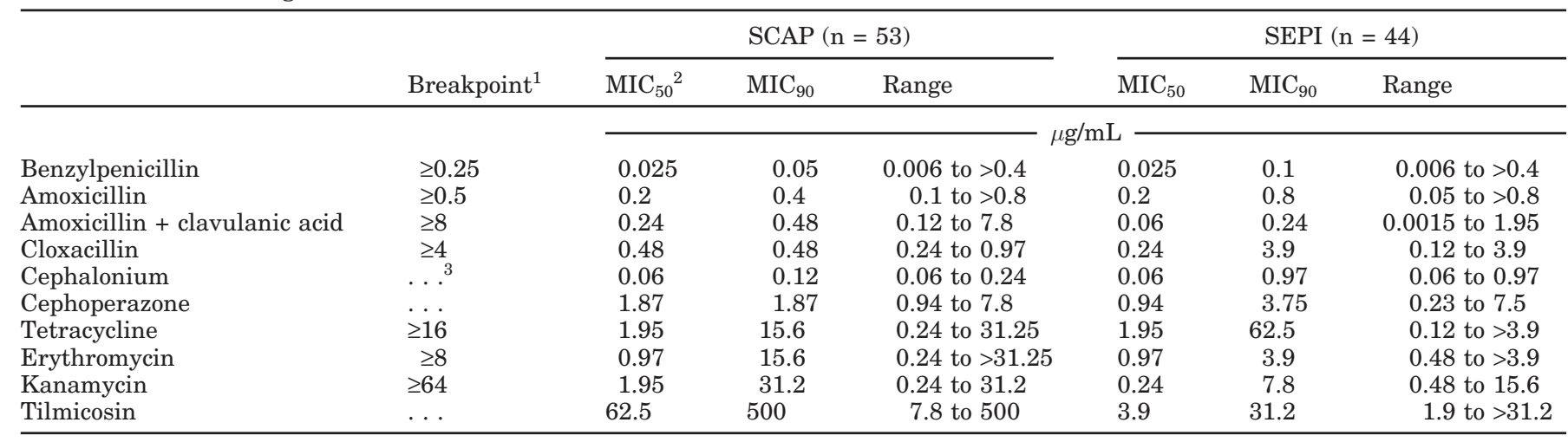

${ }^{1}$ Breakpoint values defined in the list of antimicrobial agents for routine testing of bovine mastitis pathogens, recommended by the National Committee for Clinical Laboratory Standards (NCCLS, 1997).

${ }^{2} \mathrm{MIC}_{50}$ and $\mathrm{MIC}_{90}=$ Minimum concentrations of the various antimicrobial agents required to inhibit growth of 50 and $90 \%$ of the isolates tested, respectively.

${ }^{3}$ Breakpoint value not available for this antibiotic.

\section{Antimicrobial Susceptibility}

Table 10 shows the antimicrobial susceptibility (as $\mathrm{MIC}_{50}$ and $\left.\mathrm{MIC}_{90}\right)$ of strains of SCAP $(\mathrm{n}=53)$ and SEPI ( $\mathrm{n}=44$ ) isolated from goats throughout the lactation. The $\beta$-lactamines (penicillins and cephalosporins) are used widely for intramammary treatment of bovine mastitis, and now their use is rapidly increasing for control of mammary infections in small ruminants. The $\mathrm{MIC}_{90}$ for penicillin reported in previous studies for CNS isolated in bovine IMI ranged from $0.25 \mu \mathrm{g} / \mathrm{mL}$ (Salmon et al., 1998), to $4.40 \mu \mathrm{g} / \mathrm{mL}$ (Gentilini et al., 2002), and $32 \mu \mathrm{g} / \mathrm{mL}$ (Thornsberry et al., 1997). These differences in MIC $_{90}$ values show the variability of the antimicrobial activity of penicillins against CNS and support the importance of determining penicillin susceptibility patterns for CNS.

No evidence of resistance was observed among the penicillin group, except for amoxicillin against SEPI. We observed high efficacy of benzylpenicillin against SEPI and SCAP $\left(\mathrm{MIC}_{90}=0.1\right.$ and $0.05 \mu \mathrm{g} / \mathrm{mL}$, respectively). In the penicillin group, cloxacillin showed strong activity against SCAP, as MIC ranged from 0.24 to $0.97 \mu \mathrm{g} / \mathrm{mL}\left(\mathrm{MIC}_{90}=0.48 \mu \mathrm{g} / \mathrm{mL}\right)$, but was much less effective against SEPI ( $\left.\mathrm{MIC}_{90}=3.9 \mu \mathrm{g} / \mathrm{mL}\right)$. The combination of amoxicillin plus clavulanic acid had similar effects on SEPI and SCAP $\left(\mathrm{MIC}_{90}=0.48\right.$ and 0.24 $\mu \mathrm{g} / \mathrm{mL}$, respectively). Amoxicillin alone showed slightly lower efficacy against SEPI and SCAP $\left(\mathrm{MIC}_{90}=0.8\right.$ and $0.4 \mu \mathrm{g} / \mathrm{mL}$, respectively). Considering the sensitivity of this drug to the inactivating action of $\beta$-lactamase enzymes, its effectiveness indicates that the Staphylococcus colonies isolated and tested in the present study were not $\beta$-lactamase producers. The cephalosporins are usually classified into different generations on the basis of their antimicrobial spectrum. In the present study, cephalonium and cephoperazone were included as first- and third-generation drugs, respectively. Against the CNS isolated, cephalonium showed good activity against both SEPI $\left(\mathrm{MIC}_{90}=0.97 \mu \mathrm{g} / \mathrm{mL}\right)$ and SCAP $\left(\mathrm{MIC}_{90}=0.12 \mu \mathrm{g} / \mathrm{mL}\right.$ ), whereas cephoperazone performed poorly against both CNS strains. Selected as representative drugs of each group, erythromycin and tilmicosin (macrolides), kanamycin (amino-glycoside group), and tetracycline (tetracycline group) showed moderate to poor activity against CNS tested in the present study.

\section{CONCLUSIONS}

In dairy cattle, CNS are considered important mastitis pathogens and can be the cause of substantial economic losses as these infections are associated with damage to milk secretory tissue of the mammary gland by increased connective tissue stroma (Trinidad et al., 1990), moderate increases in milk SCS (Matthews et al., 1991; Chaffer et al., 1998), and significant decreases in yield (Timms and Schultz, 1987). The role of CNS, however, as a cause of caprine mastitis is not completely clear. Our study examined the effects of the main CNS isolated in goat IMI (SCAP and SEPI) on SCS and production traits. Infections by SCAP were associated with greater SCS, although infections by SEPI tended to be more chronically persistent. No detrimental effects on milk yield were detected for infection by either species, despite the fact that a negative relationship was observed between milk yield and SCS. Infections that eventually became chronic tended to have greater SCS 
at their onset than did short-term infections. Results of our study, therefore, indicate that producers should consider SCS when deciding to use antibiotics to treat goats infected by CNS bacteria. Infected animals with low SCS may eliminate the bacteria naturally, without detrimental effects on production.

The role of CNS as a possible reservoir for resistance among Staphylococci has been determined (Archer and Climo, 1994). The potential increase in the prevalence of resistant CNS strains may present a serious problem for producers and veterinarians in the choice of an appropriate antimicrobial therapy. When a single resistant CNS is isolated from a case of caprine subclinical IMI, an effective antimicrobial therapy usually can be found. When the presence of multiple resistant CNS is detected, however, the goats should be culled. Although no clear evidence of bacterial resistance to antibiotics was recorded in this study, the emergence of this phenomenon in dairy flocks should be monitored continuously to detect susceptibility patterns, to establish trends in CNS resistance, and to determine the most effective dry therapy. In this study, great differences in the efficacy of the different antimicrobial drugs tested were observed. Finally, considering the experimental data obtained and the relatively low importance of clinical mastitis in goats, we conclude that in the control of subclinical IMI sustained by CNS (specifically SCAP and SEPI), benzylpenicillin and other drugs belonging to the wide-spectrum penicillins (such as ampicillin and amoxicillin alone or ampicillin/amoxicillin combined with drugs as $\beta$-lactamase inhibitors) could be considered the best therapeutic choice.

\section{ACKNOWLEDGMENTS}

The authors would like to thank the 2 farmers for allowing the sampling of data from their herds. In addition, we recognize Chiara Vimercati for her critical review of the manuscript.

\section{REFERENCES}

Ali, A. K. A., and G. E. Shook. 1980. An optimum transformation for somatic cell concentration in milk. J. Dairy Sci. 63:487-490.

Archer, G. L., and M. W. Climo. 1994. Antimicrobial susceptibility of coagulase-negative staphylococci. Antimicrob. Agents Chemother. 38:2231-2237.

ASSONAPA (Associazione Nazionale della Pastorizia). 2004. Online. Available www.assonapa.com. Accessed Dec. 10, 2004.

Bergonier, D., R. de Cremoux, R. Rupp, G. Lagriffoul, and X. Berthelot. 2003. Mastitis of dairy small ruminants. Vet. Res. 34:689-716.

Boettcher, P. J., L. B. Hansen, P. M. VanRaden, and C. W. Ernst. 1992. Genetic evaluation of Holstein bulls for somatic cells in milk of daughters. J. Dairy Sci. 75:1127-1137.

Boscos, C., A. Stefanakis, C. Alexopoulos, and F. Samartzi. 1996. Prevalence of subclinical mastitis and influence of breed, parity, stage of lactation and mammary bacteriological status on Coulter
Counter Counts and California Mastitis Test in the milk of Saanen and autochthonous Greek goats. Small Rumin. Res. 21:139-147.

Burriel, A. R. 1997. Dynamics of intramammary infection in the sheep caused by coagulase-negative staphylococci and its influence on udder tissue and milk composition. Vet. Rec. 140:419-423.

Chaffer, M., G. Leitner, M. Winkler, and A. Saran. 1998. Coagulasenegative Staphylococcus intermedius isolated from milk from dairy cows in Israel. Vet. Rec. 143:592-593.

Contreras, A., J. C. Corrales, A. Sànchez, and D. Sierra. 1997. Persistence of caprine intramammary pathogens throughout lactation. J. Dairy Sci. 80:2815-2819.

Contreras, A., M. J. Paape, and R. H. Miller. 1999. Prevalence of subclinical intramammary infection caused by Staphylococcus epidermidis in a commercial dairy goat herd. Small Rumin. Res. 31:203-208.

Deinhofer, M., and A. Pernthaner. 1993. Differentiation of staphylococci from ewe and goat milk samples. Dtsch. Tierarztl. Wochenschr. 100:234-236.

Deinhofer, M., and A. Pernthaner. 1995. Staphylococcus spp. as mastitis-related pathogens in goat milk. Vet. Microbiol. 43:161-166.

East, N. E., E. F. Birnie, and T. B. Farver. 1987. Risk factors associated with mastitis in dairy goats. Am. J. Vet. Res. 48:776-779.

El Idrissi, A., H. A. Benkirane, and M. Zardoune. 1994. Investigations sur les mammites subcliniques dans les élevages caprins laitiers au Maroc. Rev. Elev. Med. Vet. Pays Trop. 47:285-287.

Fthenakis, G. C., R. R. Marples, J. F. Richardson, and J. E. Jones. 1994. Some properties of coagulase-negative staphylococci isolated from cases of ovine mastitis. Epidemiol. Infect. 112:171-176.

Fuertes, J. A., C. Gonzalo, J. A. Carriedo, and F. San Primitivo. 1998. Parameters of test day milk yield and milk components for dairy ewes. J. Dairy Sci. 81:1300-1307.

Gentilini, E., G. Denamiel, A. Betancor, M. Rebuelto, M. Rodriguez Fermepin, and R. A. De Torres. 2002. Antimicrobial susceptibility of coagulase-negative staphylococci isolated from bovine mastitis in Argentina. J. Dairy Sci. 85:1913-1917.

Gonzalo, C., A. Ariznabarreta, J. A. Carriedo, and F. San Primitivo. 2002. Mammary pathogens and their relationship to somatic cell count and milk yield losses in dairy ewes. J. Dairy Sci. 85:1460-1467.

Gonzalo, C., J. A. Carriedo, J. A. Baro, and F. San Primitivo. 1994. Factors influencing variation of test day milk yield, somatic cell count, fat, and protein in dairy sheep. J. Dairy Sci. 77:1537-1542.

Gutierrez, L. M., M. L. Garcia Lopez, A. Otero, M. C. Garzia-Fernan$\mathrm{dez}$, and B. Moreno. 1990. Incidence of staphylococci in ovine mastitic milk and antibiotic susceptibility of the strain. Milchwissenschaft 45:778-781.

Heringstad, B., G. Klemetsdal, and T. Steine. 2003. Selection responses for clinical mastitis and protein yield in two Norwegian dairy cattle selection experiments. J. Dairy Sci. 86:2990-2999.

Hogan, J. S., D. G. White, and J. W. Pankey. 1987. Effects of teat dipping on intramammary infections by staphylococci other than Staphylococcus aureus. J. Dairy Sci. 70:873-879.

Kalogridou-Vassiliadou, D. 1991. Mastitis-related pathogens in goat milk. Small Rumin. Res. 4:203-212.

Lam, T. J., Y. H. Schukken, J. H. van Vliet, F. J. Grommers, M. J. Tielen, and A. Brand. 1997. Effect of natural infection with minor pathogens on susceptibility to natural infection with major pathogens in the bovine mammary gland. Am. J. Vet. Res. 58:17-22.

Leitner, G., U. Merin, N. Silanikove, E. Ezra, M. Chaffer, N. Gollop, M. Winkler, A. Glickman, and A. Saran. 2004. Effect of subclinical intramammary infection on somatic cell counts, NAGase activity and gross composition of goats' milk. J. Dairy Res. 71:311-315.

Lerondelle, C., and B. Poutrel. 1984. Characteristics of non-clinical mammary infections of goats. Ann. Rech. Vet. 15:105-112.

Luengo, C., A. Sanchez, J. C. Corrales, C. Fernandez, and A. Contreras. 2004. Influence of intramammary infection and non-infection factors on somatic cell counts in dairy goats. J. Dairy Res. 71:169-174.

Maisi, P., and I. Riipinen. 1991. Pathogenicity of different species of staphylococci in caprine udder. Br. Vet. J. 147:126-132. 
Matthews, K. R., R. J. Harmon, and B. E. Langlois. 1991. Effect of naturally occurring coagulase-negative staphylococci infections on new infections by mastitis pathogens in the bovine. J. Dairy Sci. 74:1855-1859.

Moroni, P., F. Vellere, M. Antonini, G. Pisoni, G. Ruffo, and S. Carli. 2004. Antibiotic susceptibility of coagulase-negative staphylococci isolated from goats milk. Int. J. Antimicrob. Agents 23:637-640.

National Committee for Clinical Laboratory Standards (NCCLS). 1997. Methods for dilution antimicrobial susceptibility tests for bacteria that grow aerobically. 3rd ed. Approved Standard. Document M7-A4. National Committee for Clinical Laboratory Standards, Wayne, PA.

National Mastitis Council. 1987. Laboratory and Field Handbook on Bovine Mastitis. Natl. Mastitis Counc., Inc., Arlington, VA.

Ndegwa, E. N., C. M. Mulei, and S. J. Munyua. 2001. Prevalence of microorganisms associated with udder infections in dairy goats on small-scale farms in Kenya. J. S. Afr. Vet. Assoc. 72:97-98.

Pösö, J., and E. A. Mäntysaari. 1996. Relationships between clinical mastitis, somatic cell score, and production for the first three lactations of Finnish Ayrshire J. Dairy Sci. 79:1284-1291.

Poutrel, B. 1984. Udder infection of goats by coagulase-negative staphylococci. Vet. Microb. 9:131-137.

Poutrel, B., R. de Cremoux, M. Ducelliez, and D. Verneau. 1997. Control of intramammary infections in goats: Impact on somatic cell counts. J. Anim. Sci. 75:566-570.

Poutrel, B., R. de Cremoux, R. Pillet, V. Heuchel, and M. Ducheilliez. 1996. Pages 61-64 in Caprine mammary infections with respect to cell counts in milk. EAAP Publication No. 77. R. Rubino, ed. Wageningen, the Netherlands.

Reents, R., J. C. M. Dekkers, and L. R. Schaeffer. 1995. Genetic evaluation for somatic cell score with a test day model for multiple lactations. J. Dairy Sci. 78:2858-2870.
Rodrigues da Silva, E., A. Pimenta Siqueira, J. C. Dias Martins, W. P. Barbosa Ferreira, and N. da Silva. 2004. Identification and in vitro antimicrobial susceptibility of Staphylococcus species isolated from goat mastitis in the Northeast of Brazil. Small Rumin. Res. 55:45-49.

Salmon, S. A., J. L. Watts, F. M. Aarestrup, J. W. Pankey, and R. J. Yancey, Jr. 1998. Minimum inhibitory concentrations for selected antimicrobial agents against organisms isolated from the mammary glands of dairy heifers in New Zealand and Denmark. J. Dairy Sci. 81:570-578.

Sanchez, A., C. Fernàndez, A. Contreras, and J. C. Corrales. 2002. Effect of intramammary infection by Staphylococcus caprae on somatic cell counts and milk composition in goats J. Dairy Res. 69:325-328.

Smith, R. E., and H. V. Hagstad. 1986. Infection of the bovine udder with coagulase-negative staphylococci. Prev. Vet. Med. 4:35-43.

Sordillo, L. M., K. Shafer-Weaver, and D. Derosa. 1997. Immunobiology of the mammary gland. J. Dairy Sci. 80:1851-1865.

Thornsberry, C., P. J. Burton, Y. C. Yee, J. L. Watts, and R. J. Yancey, Jr. 1997. The activity of a combination of penicillin and novobiocin against bovine mastitis pathogens: Development of a disk diffusion test. J. Dairy Sci. 80:413-421.

Timms, L. L., and L. H. Schultz. 1987. Dynamics and significance of coagulase-negative staphylococcal intramammary infections. J. Dairy Sci. 70:2648-2657.

Trinidad, P., S. C. Nickerson, and R. W. Adkinson. 1990. Histopathology of staphylococcal mastitis in unbred dairy heifers. J. Dairy Sci. 73:639-647.

Watson, D. J., and J. F. Buswell. 1984. Modern aspects of sheep mastitis. Br. Vet. J. 140:529-534. 